\title{
Study on the factors influencing the PE ratio of Baogang Group
}

\author{
Xin Ling Du ${ }^{1, a}$ and Jing $\mathrm{Li}^{1, \mathrm{~b}^{*}}$ \\ ${ }^{1}$ Beijing Normal University Zhuhai Campus, Zhuhai 519087, China \\ "Corresponding Author, Jing Li

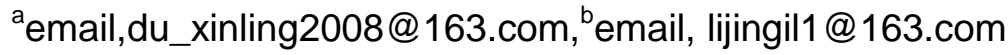

Keywords: Baogang Group; PE ratio; Macro factors; Micro factors

\begin{abstract}
The paper makes empirical analysis at micro and macro level on the influencing factors of PE ratio of Baogang Group co., LTD; the four financial indexes, inventory turnover, asset-liability ratio, current ratio and Operating profit margin are selected at the micro level, and gross domestic product (GDP), exchange rates, interest rates and inflation rates are selected at the macro level. The conclusion of the regression analysis is the micro and macro factors influencing the PE ratio contribute to the reasonable and comprehensive judgment of low and high of the PE ratio.
\end{abstract}

\section{Introduction}

Due to the high financial cost from debt investment, China iron and steel industry has the worst economic benefit among all the industries with excess production capacity. PE ratio is ratio of stock price and earnings per share, which to some extent measures the value of an enterprise, reflects market information, and even judges the economic risk of the whole market. The analysis of PE ratio for iron and steel enterprises can improve the core competitiveness of China's steel industry.

\section{Literature review of the influencing factors of PE ratio}

PE ratio is also called as the price earnings ratio or the market price earnings ratio, which is one of the evaluation index to a company's share profitability for investors; higher PE ratio indicates higher valuation of per share profitability and higher expectations to the company's future profitability. The calculating formula is:

$\mathrm{PE} \operatorname{ratio}(\mathrm{P} / \mathrm{E})=$ the general market price per share $(\mathrm{P}) /$ the common stock annual earnings per share(EPS)

In the above formula, $\mathrm{P}$ stands for the current market price; the determination of annual earnings per share of common stock may be the profit of current year, and may also be forecast earnings for the future.

Making use of market data from 1954 to 1993, Kane Marcus and Noh (1996) analyzed the market volatility, PE ratio and business cycle phase, and concluded that the PE ratio will decrease when the market volatility, real interest rates and inflation rates increase. There is positive correlation between dividend and PE ratio ${ }^{[1]}$. Basu (1997) found that a stock with low PE ratio can bring more higher yields than that of a high PE ratio, which is called the PE effect, that is a kind of "market exception" ${ }^{[2]}$. Bickham \& Luoghlin (1996) analyzed the PE ratio influential factors of S\&P 500 index from 
1968 to 1993, and concluded the significant positive correlation relationship of PE ratio with dividend payment rate and the expected growth per share ${ }^{[3]}$. White (2000) came to the similar conclusions as Luoghlin with more long-run samples ${ }^{[4]}$.

Through the analysis of the operating performance, industry attributes and size of Chinese listed companies to the influence of PE ratio, Zang Suyu (2004) concluded that the heterogeneity of the stock market is very strong; the PE ratio differs due to the difference of industry, size and style ${ }^{[5]}$. By the CPVGO model, Zhao Man(2012) came to the conclusion that PE ratio is higher if the company has better prospect or higher equity capital ${ }^{[6]}$. Under the analysis of the index of 300 stocks in Shanghai and Shenzhen stock market, Gu Yuqin(2013) arrived at the conclusion that return on equity has the greatest impact on PE ratio, and the next is turnover rate, asset-liability ratio, tradable share ratio, dividend payout ratio and beta coefficient ${ }^{[7]}$.

\section{The analysis of influencing factors for Baogang Group PE ratio}

Variable selection and data sources. According to the principle of data availability and the correlation, the macro indexes affecting the PE ratio selected in the paper are as follows: the inflation rate, GDP, exchange rate and interest rate level; the micro indexes are: the inventory turnover ratio, Operating profit margin, asset-liability ratio and liquidity ratio.

Table 1 shows the data sources of GDP, interest rate, exchange rate, inflation rate ${ }^{[8,9]}$; the data of the inventory turnover ratio, earnings per share, asset-liability ratio and liquidity ratio are from the annual financial statements of Baogang Group ${ }^{[10]}$, and the variable type and calculation are shown in table 2 .

Table 1 variable type of macro factors affecting PE ratio and data sources

\begin{tabular}{l|c|l}
\hline Variable name & Variable type & Data sources \\
\hline Interest Rate(LR) & Numeric type & Website of BOC \\
\hline Exchange Rate(ER) & Numeric type & Yearbook of China statistics \\
\hline GDP & Numeric type & Yearbook of China statistics \\
\hline Inflation Rate(PZR) & Numeric type & Website of Bureau of statistics \\
\hline
\end{tabular}

Table 2 variable type of micro factors affecting PE ratio and data sources

\begin{tabular}{c|c|c}
\hline $\begin{array}{c}\text { Variable name } \\
\text { ( ITO) }\end{array}$ & Variable type & Calculation formula \\
\hline $\begin{array}{c}\text { Operating profit margin } \\
\text { (OPR) }\end{array}$ & Numeric type & Sales inventory/inventory \\
\hline asset-liability ratio (LAR) & Numeric type & Operating profit/operating income \\
\hline liquidity ratio (CR) & Numeric type & Current assets/current liabilities \\
\hline
\end{tabular}

The basic assumptions. The assumptions of correlation of the company's PE ratio is as follows:

The negative relationship between the interest rate and $\mathrm{PE}$ ratio. The higher the interest rate, 
the lower the PE ratio; otherwise, the lower the interest rate, the higher the PE ratio.

The negative relationship between exchange rate and PE ratio. The higher the exchange rate, the lower the PE ratio; otherwise, the lower the exchange rate, the higher the PE ratio.

GDP (gross domestic product) and PE ratio are positively related. The higher the GDP, the higher the PE ratio; the lower the GDP, the lower the PE ratio.

The inflation rate and $P E$ ratio are positively related. The higher the rate of inflation, the higher the PE ratio; the lower the rate of inflation, the lower the PE ratio.

The inventory turnover rate and $\mathrm{PE}$ ratio are positively related. The higher the inventory turnover ratio, the higher the PE ratio; otherwise, the lower the inventory turnover rate, the lower the PE ratio.

Operating profit margin and $\mathrm{PE}$ ratio are negatively related. The higher the Operating profit margin, the lower the PE ratio; otherwise, the lower the Operating profit margin, the higher the PE ratio.

The asset-liability ratio and $\mathrm{PE}$ ratio are negatively related. The higher the asset-liability ratio, the lower the PE ratio; otherwise, the lower the asset-liability ratio, the higher the PE ratio.

The current ratio and PE ratio are positively related. The higher the current ratio, the higher the PE ratio; otherwise, the lower the current ratio, the lower the PE ratio.

\section{Research model}

The construction of model. Making use of SPSS20.software for simple variance analysis of the inflation rate, exchange rate, interest rate, GDP, asset-liability ratio, Operating profit margin, the inventory turnover ratio and liquidity ratio, the result of the analysis are shown in table 3.

Table 3 ANOVA $^{\mathrm{b}}$

\begin{tabular}{|c|c|c|c|c|c|c|}
\hline \multicolumn{2}{|c|}{ Model } & $\begin{array}{l}\text { Sum of } \\
\text { Squares }\end{array}$ & df & Mean Square & $\mathrm{F}$ & Sig. \\
\hline \multirow[t]{3}{*}{1} & Regression & 35786.918 & 8 & 4473.365 & 5322.304 & $.011^{a}$ \\
\hline & Residual & .840 & 1 & .840 & & \\
\hline & Total & 35787.759 & 9 & & & \\
\hline
\end{tabular}

a. Predictors: (Constant), asset-liability ratio, interest rate, inventory turnover ratio, GDP,

operating profit margin, liquidity ratio, exchange rate, inflation rate

b. Dependent Variable: PE ratio

According to the analysis results, at the significant level of 0.05 , due to the value of $p$ is less than 0.05 , the null hypothesis of significant hypothesis to regression equation should be rejected and the regression coefficient is considered impossible to be 0 . Of all the 8 factors affecting the PE ratio of Baogang Group, the confidence probability of interest rate, inflation rate, exchange rate, GDP, asset-liability ratio, Operating profit margin, liquidity ratio and the inventory turnover ratio are all above $95 \%$, and with significant differences; the results prove the assumptions and linear model can be built. 
Table 4 Coefficients ${ }^{\mathrm{a}}$

\begin{tabular}{|c|c|c|c|c|c|c|}
\hline \multirow[b]{2}{*}{ Mode } & & \multicolumn{2}{|c|}{ Unstandardized Coefficients } & \multirow{2}{*}{$\begin{array}{c}\text { Standardized } \\
\text { Coefficients } \\
\text { Beta }\end{array}$} & \multirow[b]{2}{*}{$\mathrm{t}$} & \multirow[b]{2}{*}{ Sig. } \\
\hline & & B & Std. Error & & & \\
\hline \multirow[t]{9}{*}{1} & (Constant) & -2590.663 & 103.037 & & -25.143 & .025 \\
\hline & GDP & 2.886E-5 & .000 & .770 & 88.940 & .007 \\
\hline & Inflation rate & 3.191 & .103 & 2.909 & 30.942 & .021 \\
\hline & $\begin{array}{l}\text { Exchange } \\
\text { rate }\end{array}$ & 1.074 & .067 & 1.335 & 16.025 & .040 \\
\hline & Interest rate & -35.540 & .589 & -.470 & -60.386 & .011 \\
\hline & $\begin{array}{l}\text { Inventory } \\
\text { turnover rate }\end{array}$ & 45.251 & 1.324 & .992 & 34.177 & .019 \\
\hline & Liquidity ratio & 188.618 & 3.845 & .712 & 49.058 & .013 \\
\hline & $\begin{array}{l}\text { Operating } \\
\text { profit margin }\end{array}$ & 12.316 & .237 & .769 & 51.970 & .012 \\
\hline & $\begin{array}{l}\text { Asset-liability } \\
\text { ratio }\end{array}$ & -.091 & .082 & -.018 & -1.104 & .469 \\
\hline
\end{tabular}

a. Dependent Variable: PE ratio

According to the table 4, at the significant level a of 0.05, the GDP, interest rates, inflation rates, inventory turnover rates, operating profit margin and liquidity ratio all reach significant level; the other variables without reaching significant level should be eliminated and new models be built.

Table 5 Theoretical inspection of regression

\begin{tabular}{|c|c|l|l|c|}
\hline Variable & coefficient & $\begin{array}{c}\text { Theoretical } \\
\text { assumption }\end{array}$ & Actual result & Consistency \\
\hline GDP & $2.886 \mathrm{E}-5$ & Forward direction & Forward direction & Positive \\
\hline Inflation rate (PZR) & 3.191 & Forward direction & Forward direction & Positive \\
\hline Exchange rate (ER) & 1.074 & Reverse direction & Forward direction & Negative \\
\hline Interest rate (IR) & -35.540 & Reverse direction & Reverse direction & Positive \\
\hline $\begin{array}{c}\text { Inventory turnover } \\
\text { rate (ITO) }\end{array}$ & 45.251 & Forward direction & Forward direction & Positive \\
\hline $\begin{array}{c}\text { Operating profit margin } \\
\text { (OPR) }\end{array}$ & 12.316 & Forward direction & Forward direction & Positive \\
\hline Liquidity rate (CR) & 188.618 & Forward direction & Forward direction & Positive \\
\hline $\begin{array}{c}\text { Asset-liability rate } \\
\text { (LAR) }\end{array}$ & -.091 & Reverse direction & Reverse direction & Positive \\
\hline
\end{tabular}

After inspection, the other variables without exchange rate have significant correlation with explained variables, which means the previous hypothesis is accepted, so GDP, liquidity ratio, asset-liability rate, inventory turnover rate, inflation rate and interest rate are selected as independent variables. The model of regression equation is: 


$$
\mathrm{P} / \mathrm{E}=\mathrm{C}+a G D P+b C R+\mathrm{cLAR}+\mathrm{dITO}+\mathrm{fIR}+\mathrm{eTHL}
$$

Table 6 Modified model Coefficients ${ }^{\mathrm{a}}$

\begin{tabular}{|c|c|c|c|c|c|c|}
\hline \multirow{2}{*}{\multicolumn{2}{|c|}{ Model }} & \multicolumn{2}{|c|}{ Unstandardized Coefficients } & \multirow{2}{*}{$\begin{array}{c}\begin{array}{c}\text { Standardized } \\
\text { Coefficients }\end{array} \\
\text { Beta }\end{array}$} & \multirow[b]{2}{*}{$\mathrm{t}$} & \multirow[b]{2}{*}{ Sig. } \\
\hline & & $\mathrm{B}$ & Std. Error & & & \\
\hline \multirow[t]{7}{*}{1} & (Constant) & -956.145 & 124.521 & & -7.679 & .005 \\
\hline & GDP & $2.661 \mathrm{E}-5$ & .000 & .710 & 9.425 & .003 \\
\hline & Inflation rate & 1.623 & .146 & 1.479 & 11.099 & .002 \\
\hline & Interest rate & -31.125 & 4.980 & -.412 & -6.250 & .008 \\
\hline & $\begin{array}{l}\text { Inventory } \\
\text { turnover rate }\end{array}$ & 24.489 & 3.194 & .537 & 7.668 & .005 \\
\hline & Liquidity ratio & 165.387 & 34.307 & .624 & 4.821 & .017 \\
\hline & $\begin{array}{l}\text { Operating } \\
\text { profit margin }\end{array}$ & 15.014 & 1.369 & .938 & 10.964 & .002 \\
\hline
\end{tabular}

a. Dependent Variable: PE ratio

The model is:

\section{$\mathrm{P} / \mathrm{E}=-956.1+2.7 \times 10^{5} \mathrm{GDP}+1.6 \mathrm{PZR}-31.1 \mathrm{IR}+24.5 \mathrm{ITO}+165.4 \mathrm{CR}+$}

\subsection{PR}

The result analysis. The empirical results show that GDP, inflation rate and interest rate in macro factors accept the hypothesis-testing, and have significant correlation with PE ratio, which is in favor of government adopting policy methods from macro-aspects and the increase of PE ratio. In the micro factors, the asset-liability rate rejects hypothesis-testing.

\section{Conclusion}

The government should take appropriate policies of exchange rate and interest rate, increase import and export, provide financial subsidies for the iron and steel enterprise. Meanwhile, perfect the legal system of the stock market, crack down on internal operation, increase the intensity of punishment, reduce the excesses of the market, improve the enthusiasm of investors and raise prospect of the iron and steel industry for investors. Baogang Group should also reduce the production cost, introduce new technology, and further improve the internal system, the staff quality, the productivity and quality. The PE rate level can only be raised by comprehensive development of macro and micro factors.

\section{References}

[1] J.Q. Ma: Modern Economic Information, (2008).No5.P.113

[2] P.K. Basu: Theory of Optical Processes in Semiconductors: Bulk and Microstructures: Bulk and 
Microstructures. (Oxford University Press, England 1997 )

[3] Bickham J W. Patton \& TR Loughlin: Journal of Mammalogy, (1996) No77.P. 95

[4] C.B. White: Financial Analysts Journal, Vol56. (2000)No6.P.30

[5] S.Y. Zang: Journal of Chongqing institute of technology, Vol18. (2004) No3.p.105

[6] M. Zhao: Modern business, (2012) No 35.p.52

[7] Y.Q Gu, The analysis of the affecting factors of company PE ratio, Modern economy, (2013) No24.P.142

[8] http://data.stats.gov.cn

[9] http://app.finance.ifeng.com/data/stock/cwzb.php?symbol=600010

[10] http://www.pbc.gov.cn/publish/zhengcehuobisi/631/2014/20141128101510852816551/2014

1128101510852816551. html

[11]J. Li: PE ratio, earning quality and firm value: analysis based on the empirical data of Chinese a-share companies. (Economic Science Press, China 2008), P.6

[12] W. Xue: Statistic analysis and application of SPSS. (China Renmin University Press, China 2011), P.247 